DOI: $10.1515 /$ rpp-2015-0022

PhD in Pedagogical Sciences, Associate Professor, TETIANA BRANITSKA Myhailo Kotsubynskyi State Pedagogical University of Vinnytsia, Ukraine Address: 32 Ostrovskogo St., Vinnytsia, 21001, Ukraine E-mail: tatjana_rom@mail.ru

\title{
THE FORMATION OF FUTURE SOCIONOMIC EXPERTS' CONFLICTOLOGICAL CULTURE IN GERMANY AND AUSTRIA
}

\begin{abstract}
At the present stage of Ukrainian society development there is a requirement for studying and the analysis of the maintenance of experts' preparation in social, socially pedagogical sphere in foreign countries. Therefore the great value has research of experience in theoretical and practical preparation of the future socionomic experts in the universities of Germany and Austria.

In the article the formation of socionomic future experts' conflictological culture and teaching features of social-pedagogically directed disciplines in high schools of Germany and Austria have been considered. The analysis of the scientific and pedagogical literature devoted to studying separate aspects of socionomic experts' conflictological culture formation has been carried out. The standard-legal maintenance of future social teachers' vocational training in high schools of Germany and Austria, in particular, features of curricula, their substantial filling, and also training specificity have been investigated. Presence of the conflictological component in the frame of future socionomic experts' preparation has been designated, that allows students to raise efficiency of professional work in the future.

Improvement of the programs and subject content able to open peculiarities of future socionomic experts' psychological pedagogical and conflictological preparation in Germany and Austria will promote formation of the modern competitive expert with a high level of conflictological culture.

Key words: socionomic occupations, vocational training, the future experts, sociallypedagogical disciplines, conflictological culture.

\section{INTRODUCTION}

The systems of higher education in Ukraine and in European countries have been acquiring more and more common features lately. Although there is a developed system of pedagogical staff preparation in Ukraine, the experience of the advanced European countries is studied and the newest methods and means of the future experts' vocational training are adopted.

Ukraine's integration into the polycultural European space demands introduction of new standards, concepts and technologies in the educational sphere. The European countries are a vivid example of a harmonious combination of all these aspects for achievement of the education system main objective, namely the preparation of highly skilled teachers.

Modern communication allows interchanging theoretical and practical experience of professional staff preparation among different countries. Systematisation and justification of this experience will help its active introduction into Ukraine education system, adoption of the best samples in the socionomic experts' conflictological preparation.
\end{abstract}




\section{THE AIM OF THE STUDY}

To generalise practical experience of future socionomic experts' conflictological culture formation in Germany and Austria for its use in the Ukrainian system of social teachers' preparation.

\section{THEORETICAL FRAMEWORK AND RESEARCH METHODS}

The professional training of socionomic experts in Germany and Austria is investigated by many Ukrainian scientists and teachers, including N. Abashkina, J. Chemodurova, V.Gamanjuk, T. Jarkina, P. Kagan, A. Kovalenko, A. Ligotsky, S. Malkova, A. Piskunov, A. Prishljakm, L. Puhovsky, M. Sokolova, I. Trilinsky, T. Vakulenko, G. Vashchenko and many others.

In the study the complex of interdependent theoretical methods that provided possibility of interdisciplinary knowledge has been used, in particular, theoretical methods: the analysis of conflictological culture problem in the context of ethics, sociology, psychology and pedagogics; the relative method, that allowed to compare various concepts of conflictological culture development to reveal their general and special features; the comparative analysis and experience systematisation of the future socionomic experts' conflictological culture formation in Germany and Austria.

\section{RESULTS}

Nowadays there is no unique model of the future teachers' preparation for all federal lands in Germany. Each of them has the frame of the educational institutions for which original approaches to teachers' vocational training are rather characteristic. In German universities students are given much more training time than in Ukraine, as it comprises fourteen semestres at the universities and more than nine semestres at branch institutes (Kozak, 2000).

Vocational training of a social teacher in Germany can be received in the following three types of educational institutions: universities, the high vocational schools and professional academies.

In Germany the high vocational schools of an applied direction (HVS) are becoming popular. Some educational institutions preparing social teachers for the last years are being reorganisedm though. HVS are united with universities, and specialised institutes of social pedagogics are created.

For German professional academies alternation of theoretical and practical blocks $(50 \%$ to $50 \%)$ is inherent. Pecularities of these educational institutions imply training students to be directed by social establishments. These factors positively influence practical preparation of the future social teachers as they, having a certain experience, can easily get a job and in the nearest future become the experts, having confirmed the educationalqualifying degree "Bachelor of Arts" (Prushliak, 2008).

For example, the future social teachers' training in Stuttgart professional academy is carried out at the faculty of social education. The educational contract is signed for three years during which the student is equated to the worker of an establishment and receives payment for his/her work. Also student employment after the end of training is quite possible.

Training at Stuttgart professional academy proceeds 3 years (6 semestres). In each semester three months are dedicated to theoretical training and practical preparation at the social establishment and at the establishment according to preliminarily concluded agreement. The academy suggests receiving the following specialities: the children's home tutor, social work in justice sphere, in the public health services system, in the establishments of granting of social leaving services, in the system of social services. 
During the first three semestres all subjects are obligatory, and during the following three ones students study subjects, obligatory both optionaly and according to the chosen specialisation.

According to the curriculum a number of obligatory subjects are as follows: "Social pedagogics and social work", "Psychology", "Sociology», "Social economy", "The Law and control", "Social medicine", "Media pedagogics", "Philosophy", theoretical practical seminars and seminars on various specialisations. The obligatory subjects are "Social consultation", "Social support: the work schema", "Presentation and public relations commenting", "Project development", "Main foundations of quality criteria empirical developmentt", "Qualitative methods", "the Internet and social work", "Scientific management and information communicative technologies". Also students study the following subjects optionaly: "Mastering social work methods", "Sociotherapy", "Intermediary", "Research in the social work", "The Information society and the social work", "The Selected themes of social economy".

The block of social-pedagogical direction disciplines such as "Social pedagogics / social work" in Stuttgart professional academy is obligatory and studied throughout all semestres. It includes both subjects of a pedagogical direction, and the subjects, concerning social work and social policy (Prushliak, 2008).

So, subjects of the psychological direction study not only those students who specialise in this sphere, but also the future experts of socionomical sphere. This results from the fact that social workers should be able to find appropriate approaches to people,

should have educed skills of interpersonal dialogue, it is necessary for them to learn how to help people to avoid conflict situations and if necessary to be able to solve them in a rational way.

Practice in the academy occupies half of school hours and lasts for 18 months. For students there are created wide opportunities for practice, accordingly experience receiving, responsibility studing, professional skill sharpening. Students have a freedom of action, receive consultations from establishments and institutions employees where they take practice.

Practice positive sides are the formation of their own style of communication with the help of knowledge on psychology, understanding of problems which can occure during communications, possession of effective dialogue methods.

HVS were created during the educational reform in 1971 according with "The Law on HVS of German lands". Their preparation of experts is carried out on the diphasic model providing one year internship in the professional area after three years of training (internship is paid). Only after that students receive the diploma. During their practice in the social establishments the job of students is not paid, the academic load does is not reduced.

Some HVS offer the integrated program of preparation in "Social pedagogics / social work" after which the student receive the diploma of the social teacher / the social worker. But there are cases, for example, in Munich HVS when students study at the specialities of "Social work", and after training receive the diploma of the social teacher.

The subjects in HVS can be aggregated as follows:

- social sciences (sociology, social policy, political science, economy, statistics, empirical social researches);

- social work and social pedagogics (history, the theory, the organisation and institutes, methods); 
- psychology / pedagogics (progressive pedagogics, therapeutic methods, the theory and practice of formation, the socialisation theory);

- public health services (medical aid rendering, institutional and official structure, medical examination);

- legal and public control (the legislation concerning youth, social security, social guarantees, work and control);

- music, dramatic art, sports, art, cinematography, work with mass media.

HVS programs provide learning of foreign languages: English, French, Spanish, and also languages of emigrants. Certain schools study disciplines of the theological direction. For example, at the Zigen versatile higher school for mastering educational qualifying level of the Bachelor students study during six semestres. After the end of training they should fulfil "year of a professional recognition" and only after that will receive the diploma.

The program of Bachelors' vocational training includes three groups of subject matters (the basic, special and general).

The basic disciplines are: "the General pedagogics", "Social pedagogics", "Didactics", "Procedure of social pedagogics and social work", "Psychology and sociology". Special disciplines are: "Aesthetics and communications", "Policy/ social administration / economy", "Law", "Social medicine / social psychiatry", "Social philosophy / social ethics". General disciplines are: "Methods of scientific researches", "Professional work sphere", "Professional work methodics".

During the whole training there is a students' preparation for research activity and entrance to the magistracy. Within the first academic year the program of Bachelors' preparation provides a weekly attendance of the following disciplines: "Methods of carrying out scientific research", "Methods of empirical scientific research" and "Statistics" that promotes their preparation for realisation of scientific researches.

The majority of the universities in Germany have special programs of social teachers' vocational training.

For example, at the pedagogical faculty of Dresden Technical university the training lasts nine semestres. Four semestres of the initial stage include two-month practice. The basic grade level comes to the end with passing examinations and thesis preparation after the ninth semester.

At the training initial stage the following disciplines are provided: "Social pedagogics", "General pedagogics", "Social scientific research methods", "Jurisprudence", and also foreign language and disciplines of an additional speciality ("Sociology" and "Psychology" are among them).

So, during training at the initial stage students receive knowledge about dialogue art, conflicts which are inevitable during dialogue, thus initial conflictological knowledge is formed. It will allow the future socionomic experts to learn avoiding conflicts, to distinguish styles of participants' behaviour in the conflict situations, to promote their decision.

At the stage of the basic training students continue to study "Social pedagogics" within the limits of the selected specialisations, "General pedagogics", the chosingly obligatory subjects ("Social-scientific methods of research", "Jurisprudence") and specialisation disciplines.

The professional training includes the following blocks of subject: public and private education of preschool age children, social pedagogical work with children and the youth; the social pedagogical help in education; social-pedagogical consultation and general help; 
social administration; sociocultural work; disciplines of the chosen specialisation; obligatory subjects choosingly.

Among obligatory subjects are offered: "Carrying out scientific research and research methods in pedagogics", "Aesthetic education", "Media pedagogics", "Bases of information technology", "Political science", "Philosophy", "Pedagogics" and "Jurisprudence".

For example, in Germany the psychologists' professional training is carried out on the university basis during two periods. The first, namely basic education, provides future experts' mastering general psychology, methods / statistics, physiology, development psychology, social psychology and personality psychology. This period lasts 9 semestres, accordingly two semestres in a year (only 3,5 years of training). The second period is the basic training providing students' mastering certain specialisation (clinical psychology, organizational psychology, psychology in formation, etc.). This period lasts during 4 semestres ( 2 years of training).

The research work at the universities is the obligatory component of the educational process. Thanks to it students learn to analyze scientific texts, to reveal problems and to find paths of their decision, to make out results of the activity in written form and to defend them on public statements.

At the universities of Germany the basic forms of classes conducting are lectures, seminars, professional practical seminars, practical exercises, colloquia, preparation of designs and abstracts. Students' educational groups are also formed aimed at studying certain separate disciplines (Prushliak, 2008). Such receptions of training promote formation and development of future socionomic experts conflictological cultures.

In German universities the preference is given to active methods of training since they educe creative independent thinking; help to obtain professional knowledge with their direct application. The curriculum provides students' independent work that forms the responsibility, self-checking, incline to search ways for different problems solutiob (Abashkina, 2003).

As for professional training of social teachers in Austria it is carried out by various types of educational institutions: schools of social work, teacher training colleges, academies, universities and other educational establishments (institutes) which have the university status. Educational functions carry out also courses of professional qualification increase.

The various aspects analysis of social teachers activity in horte (out-of-school establishment of full day guardianship of school age children) gives the grounds to assert that professional competence of the social teacher in such establishments of Austria is based on fundamental scientific knowledge (language, mathematics, the literature, natural sciences, etc.), as well as the special psycological-pedagogical knowledge.

Social-pedagogical work in horte demands general-theoretical knowledge on pedagogics, social pedagogics and psychology, in particular concerning mental development of children and the youth of school age, their requirements; theories of social education and group work, and also work in collective; leisure pedagogics; adults pedagogics and the organisation of cooperation with parents; methods of encouragement of children to training; features of work with pedagogical started children etc (Pavlishak, 2008). Knowledge of a psychologic direction has special value as the work with children demands observation, ability to operate a situation, to adjust children to a positive way, to learn how to prevent occurrence of conflict situations that can negatively affect the child's psychics. 
For Austria social teacher's work with various types of families is inherent, in particular with children of jobless families, lonely mothers, migrants, persons of "risk group" and others. During the work with such families the social teacher should propagandise ideas of children education in the family, select expedient means to help children, render social-pedagogical consultation to parents and children, to promote cooperation of family with various establishments and the organisations in the decision of essential problems.

The purpose of social teachers' training in Austria is the reception of penetrating theoretical knowledge, practical skills and professional bases of the social teacher qualification. The training maintenance is realized through curricula, programs, rellevant scientifical-methodical and educational literature. The curricula define a complex of disciplines (obligatory and optional disciplines) that provides social teacher's theoretical and practical preparation.

The most widespread methods of training in Austria are: employment-discussion, a method of biographic researches, supervision, training (consultation), a method of theatrical pedagogics. These methods have their own specificity and are differently realized, but have one purpose, namely to educate future socionomic experts.

For formation of future social teachers' conflictological cultures the practice is extremely important. It is directed at strengthening of connection benweetn the theory and future applied sphere, students' abilities formationto perform social pedagogical work.

In Austrian educational institutions preparing social teachers, the third of all school hours is dedicated to practice. It is carried out in four stages. At the first stage there is teaching of the social-pedagogical activity theoretical block, a discussion of vital topics and problems students face the most often. The second stage is continuous practice which students must pass in one of the sociall pedagogical work directions within two hours per week. At the third stage students have fortnight practice between educational semestres. Last stage provides obligatory practice during summer vacations (Pavlishak, 2008)

In the field of psychology 3 years of higher education (Bachelor degree) are not sufficient for the scientific and professional purposes, and only provide initial level of psychologist's preparation. In certain cases, for example, in Australia and Germany, the level of post-graduate preparations includes the Master's and professional doctor's levels. In all European countries where licensing and legal regulation of psychological occupation have been correctly organised, it is necessary to have Master's degree. After the rank of psychologist is defended, for one or two years it is necessary to complete practical training under supervision of the professional to become a psychologist.

Psychology professional development is structured. The majority of curricula in the psychology field demands presence of significant experience. For example, in Denmark and Austria the majority of psychologists have decided to perform further practical training.

Almost all universities have changed classical German degree to the diploma of the international Bachelor degree (basically of 3 years) and Master degree (in the basic 2 years). Bachelor's and Master's programs should be confirmed by accreditation authorities.

Students who aspire to receive Bachelor degree in the psychology field, should get education from various psychologic disciplines.

Bachelor degree prepares students for various workplaces, but the majority of students continue training to receive Master degree. Master's programs strongly differ between establishments and provide vocational education from one or several psychologic disciplines. Master degree in Psychology is a necessary condition for more responsible and exacting occupations, such as psychologists in different branches. It grants students the 
right to get education of the psychotherapist, and also to pass other courses of qualification improvement.

Almost $80 \%$ of all graduates in psychology have passed additional professional programs to become the certificated clinical psychologists. However the majority of graduates do not work as clinical psychologists, but rather find the job in various sectors of public health services, education or in the organisations.

In Austria there are 5 universities which offer Bachelor degree, Master and doctoral studies on psychology. There are also other institutions, offering to obtain education of the psychologist. In 2011 Austrian psychologists have celebrated the 20th anniversary of the Austrian Law on the psychologist.

European Federation of Psychologists Association positions the general reference point for the academic and professional competence of the countries-partners. EFPA is a federation of 25 countries-participants of the European Union and seven other European countries including all 32 European national psychologic associations. It is of great importance for all countries-members, as all professional services are given by psychologists who adhere to accurate principles of professional etiquette.

\section{CONCLUSIONS}

So, the experience of Germany and Austria in preparation of the future socionomic experts affirms that each university applies such training methods which help students in the educational process not only to acquire theoretical knowledge, but also to be able to apply knowledge to practice. Besides, in Germany and Austria dynamic training methods are used since they help students to think, form the personal data, to be able to discuss and settle own position (but not to invoke appearance of conflict situations), better know the chosen specialisation.

Perspectives for further studies are the justification of the formation system of future socionomic experts' conflictological culture.

\section{REFERENCES}

1. Badry, G., Buchka, M., Knapp, R. (1992). Pädagogik Grundlagen und Arbeitsfelder [The bases of pedagogical study]. Berlin : Luchterhand, p. 389 (in German).

2. Pavlishak, O. (2007). Die Ausbildung der Sozialpädagogen an den Hochschulanstalten in der Ukraine [The social pedagogic's work in the higher establishments of Ukraine]. Kontakte [Contacts], No 4, p. 70-78 (in German). Stover, M. (1995). Studium in Deutschland [The study in Germany]. Bonn : Kollen Druck und Verlag, p. 367 (in German).

3. Абашкіна, Н. (2003). Підготовка сочіальних педагогів у Німеччині [The preparation of social teachers in Germany]. Київ : Publising House “Автореферат”, p. 30 (in Ukrainian).

4. Бобраков, С. (2012). Особливості професійної підготовки вчителів у вищих педагогічних иколах Німеччини [Pecularities of teachers profissional training in German higher pedagogical schools] Retrieved 16.12.2014 from : http://library.udpu.org.ua/library_files/poriv_ped_stydii/2012/2012_2_12.pdf.

5. Бобраков, С. (2003). Порівняльний аналіз узагальненого досвіду професійної підготовки вчителів у ВНЗ Німеччини та України [Comparative analysis of common experience of teachers' professional training at Geman and Ukrainian universities]. Comparative-pedagogical studies, No 2-3 (16-17), p. 152-157 (in Ukrainian). 
6. Козак, Н. (2000). Дидактичні основи професійноӥ підготовки майбутніх учителів у ФРН (II половина XVIII - кінець XX cm.). [Didactic basis of teachers professional training in FRG (the second half of XVIII - the end of XX cent.)]. Abstract of thesis for a Candidate's Degree in Pedagogical Sciences. Kyiv, p. 17 (in Ukrainian).

7. Павлішак, О. (2008). Професійна підготовка соиіальних педагогів в Австрії [Professional training of social teachers in Austria]. Abstract of thesis for a Candidate's Degree in Pedagogical Sciences. Drogobych, p. 22 (in Ukrainian).

8. Пришляк, О. (2007). Змістовий компонент професійної підготовки соціальних педагогів у Німеччині [Contextual component of professional training of social teachers in Germany]. Наукові записки Тернопільського національного педагогічного ун-ту ім. В. Гнатюка [Scientific Notes of Volodymyr Gratuk Ternopil National Pedagogical University], No 1, p. 39-44 (in Ukrainian).

9. Пришляк, О. (2008). Професійна підготовка сочіальних педагогів у вищих навчальних закладах Німеччини [Professional training of social teachers at German higher establishments]. Abstract of thesis for a Candidate's Degree in Pedagogical Sciences. Ternopil, p. 34 (in Ukrainian).

10. Романовська, Л. (2013). Система підготовки фахівців з соціальної роботи за кордоном на прикладі розвинених країн [The preparation system of social work teachers at the highly developed countries]. Вісник Національної академї Державної прикордонної служби Украӥни. Серія: Педагогічні науки [Messenger of National Academy of State frontier guards of Ukraine]. Series: Pedagogical Sciences], No 3, p. 15 (in Ukrainian).

11. Сакун, Л. (1998). Підготовка професійних кадрів у Німеччині [Professional teachers preparation in German]. Рідна школа [Native School], No 4, p. 23-26 (in Ukrainian). 